\author{
REVIEW ESSAY
}

\title{
LEARNING FROM THE POLITICAL THEORIES OF THE YOUNG
}

\section{Philippa Collin}

A review essay based on Constance Flanagan’s 2013 book, Teenage Citizens: The Political Theories of the Young. Cambridge, MA: Harvard University Press. ISBN: 978-0-674-04862-1.

Philippa Collin is a Research Program Leader of the Young and Well Cooperative Research Centre and a Senior Research Fellow at the Institute for Culture and Society, University of Western Sydney, Building EM, Parramatta Campus, Locked Bag 1797, Penrith NSW 2751, Australia. E-mail: p.collin@westernsydney.edu.au

While recent years have seen a burgeoning interest in situated and comparative analysis of youth civic engagement and political participation, questions of political socialisation have received relatively less attention. This is in part the product of a branching of scholarship in youth political participation underpinned theoretically by either a developmental or a social model of childhood and youth. Despite moving away from the classic theories of stage-based development, such as those offered by Piaget and Freud, towards a life-course perspective, developmental approaches have nonetheless often positioned young people as "becoming citizens". In contrast, studies adopting a social model have argued for a difference-based conception of children and young people (Lister, 2008) "as citizens" whose political opinions and actions are obscured by adult-centric discourses and social structures. Consequently, though much of the research and collaboration in the field has been interdisciplinary, these two strands have developed in distinct trajectories. Yet both have tended to focus on what can be identified, measured, or qualified regarding what young people "know" and "do", failing in the process to sufficiently explain how political socialisation is achieved (Frazer \& Emler, 1997; Henn, Weinstein, \& Wring, 2002; Coleman \& Rowe, 2005). 
The field of political socialisation, with its roots in functionalist and developmental psychology, has also met with criticism, particularly for its tendency to focus on system stability and not the development of political subjectivities, communities, and cultures (for a good summary, see Edwards, 2012). In her new book, Teenage Citizens: The Political Theories of the Young, Constance Flanagan seeks to address these concerns. While pursuing a largely normative project, Flanagan breaks with many of the theoretical and methodological traditions of the field to focus on the question of what young people make of politics: how they conceptualise political issues, their role as citizens, and their place within formal political processes. As with much research in the field, she examines knowledge and attitudes but takes a youth-centred approach that emphasises how young people make meaning of such central concepts in democratic theory as the state, equality, trust, and participation. Her use of a life-course approach acknowledges development and change throughout life, not just in adolescence, and the key role of context, but stops short of invoking a generational line.

Impressively drawing together over two decades of research and data from four different studies, Flanagan explains how teenagers develop political feelings, ideas, and capabilities. Significantly, she weaves together quantitative and qualitative data in her analysis, ensuring that general and specific views can be adopted. The voices of young people are clearly presented and are the foundation of Flanagan's claim that young people develop "socially mediated political lay theories" based on "their experience of the terms of the social contract that binds them to other members of their communities" (p. 228). The concept of a social contract is, as Flanagan acknowledges, highly problematic. Nevertheless, she deploys it as a conceptual tool to analyse the relationship between the dominant political, economic, cultural, and social arrangements of society, and young people's everyday interactions in local institutions and relationships.

To make this claim, she first establishes the critical role of context through discussion of data from a study comparing stable western democracies (the United States, Australia, and Sweden) with countries whose democracies were in "transition" or "flux" (Bulgaria, the Czech Republic, and Hungary). From there the analysis is largely grounded in research in the United States, and while the specifics of the studies, measures, and analysis are not always easy to discern due to the presentation of this material, the overall structure of the book is clear and the writing is sophisticated, but accessible. Covering substantial theoretical terrain and drawing in much empirical data, the book presents a summary of the conceptual framework of the research, followed by chapters looking at youth perspectives on the role of the state; notions of national identity and citizenship; definitions of democracy; laws, regulation, and public good; inequality; social trust; and community service. Through use of diverse data, Flanagan shows that young people develop ideas and commitments to civic norms and values, in their everyday contexts of home, school, and community and through the interpersonal relationships constituted therein, notably those of parents, peers, and teachers. It is somewhat surprising then, that significant features of contemporary youth everyday life — especially the media and the Internet — are not considered.

\section{New Contexts and Networks of Political Socialisation}

There is now a sizable body of work that demonstrates that young people have a more expansive conception of politics and participation than is commonly captured in most quantitative research (see Harris, Wyn, \& Younes, 2007; Marsh, O’Toole, \& Jones, 2007; Harris, 2013; Collin, 2015). This literature points to the increasing, if uneven, role of the Internet and other technologies for youth political practice: seeking news, information on 
issues and politics, communicating with peers and relatives, joining or participating in online organisations or interest groups, cultural expression, and exploring views on social and political issues (Stanyer, 2005; Vromen, 2007; Banaji \& Buckingham, 2013). While there are widely divergent standpoints on the extent to which the Internet mobilises new political actors or increases engagement, it is generally accepted that social life is increasingly digitally mediated and networked. And while going online is a daily activity for most young people in advanced western democracies, quality of use and access continues to be shaped by social structures such as gender and socio-economic and cultural background (Mossberger, 2007; Vromen, 2007; boyd, 2014).

Where Flanagan is primarily interested in how young people develop views and values, scholarship in the area of digital participation has theorised a range of characteristics salient to contemporary youthful "political subjectivities" (Edwards, 2012) or to what Loader, Vromen, and Xenos (2014) term the "networked young citizen". These include an explicit emphasis on identity, personalisation, participation, and horizontal relations for civic and political engagement. These approaches often examine how young people conceptualise and engage with politics, and the relationships, practices, and contexts that feature in the formation of political subjectivity. These approaches take seriously the role of online and networked media in ways that are directly relevant to Flanagan's project. For example, while her finding that exposure to controversy - a key factor in the development of an ethic of civic participation - has particular policy implications in the domains of family and education, this also connects with research on how information and ideas travel online shaping understanding and views of political issues. For example, while some are concerned about an "echo chamber" effect, recent international comparative research finds that regular review of a social media news feed can expose young people to incidental information on political issues and activities they might not otherwise be knowledgeable about or interested in (Xenos, Vromen, \& Loader, 2014).

Studies also point to the way participation and membership in community, faith, and interest-based organisations are changing, theorised variously as a decline in social capital (Putnam, 2000) or a shift from what Norris has termed "a politics of loyalty" (i.e., loyalty to traditional political actors, organisations, institutions, and processes) to a "politics of choice" (i.e., embracing new forms of participation, new targets for political expression, and forms of collective action) (Norris, 2002, 2003). While young people may not be undertaking volunteer activities or membership in traditional organisations such as churches, charities, and political parties (Collin, 2008), they are, nevertheless, what Harris and colleagues have termed “joiners" (Harris et al., 2007) who are likely to participate in online and local activities run by community groups, organisations, and networks. Key to this is an acknowledgement of changes to the form and engagement strategies of some community organisations in the context of the affordances of digital technologies and the personalisation of politics (Chadwick, 2007; Vromen, 2011; Collin, 2015). Though Flanagan points to the important role of community organisations as sites for community service and "service learning”, she does not consider the implications of such shifts.

This highlights another significant question: How can understandings of the processes underpinning the development of political identity support a move beyond a narrow focus on what should be done to young people and their immediate contexts to broader questions about the kinds of political cultures and public institutions that engage with and serve the interests of "teenage citizens"? 


\section{The Role of Formal Political Institutions and Policy Discourses}

From the outset, Flanagan challenges narrow conceptions of politics "as the business of government and the result of electoral contests" (p. 1) arguing, as have others in political sociology, that politics concerns membership of communities and the practices of shaping the kind of society we want to live in (Vromen, 2003). She focuses on the connections between the development of political views and behaviours, historically and culturally embedded practices and beliefs, and the sites where political socialisation takes place to demonstrate that the political theories young people develop tend to reflect their context. This acknowledges how young people's views are influenced by the macro social, political, and economic arrangements of societies but does not specifically examine how their lived experiences are shaped by the principles and practices of the political systems in which they live. Yet research in both the United Kingdom and Australian contexts demonstrates that young people are sensitive to the ways in which they are constructed by the political system: as citizens-in-waiting, and as either deficient or apathetic (see Marsh et al., 2007; Collin, 2015). In my own research with young people in Australia and the United Kingdom, young people described feeling sidelined by formal political processes and actors and believed that decision-makers and other political elites discounted and delimited their views and interests (Collin, 2015). Such insights lead to one of the most crucial questions of our time: How can new knowledge about the development and nature of contemporary political identities inform a rejuvenation of political institutions, processes, and culture in order to bridge the disconnect and lack of trust that young — and old — citizens report in relation to formal political institutions and actors?

In the Coda, Flanagan tentatively responds to this question by arguing for more opportunities for young people to participate in community-level decision-making. However, how such a recommendation translates to broader institutional and political processes is not explored. As Vromen and I have argued, a focus on how this can be achieved is critical given the persistent disconnect between the views of young people and policy-makers regarding the role young people can play in policy processes (Vromen \& Collin, 2010).

\section{Can Paying Attention to Young People's Views Give Hope for the Future of Democracy?}

Flanagan's empirical exploration of the political theories of the young provides an opportunity to revisit, reconsider, and challenge established theories of what politics means in contemporary society and how it is learned, enacted, and negotiated. Consistent with several decades of research on youth participation, Flanagan finds that young people are more politically engaged when they can influence decisions and outcomes in meaningful ways, and she calls for educators, politicians, public servants, community leaders, and parents to engage in dialogue with young people. But her discussion of the policy implications is disappointingly brief. She does not, for instance, tackle the question of what kinds of politics, policies, and public institutions can foster democratic norms and values capable of both genuine engagement with people young and old and effectively dealing with the complex policy issues of our times. Her commitment to a civic republican conception of the role of civic engagement for the cultivation of good citizens reinscribes young people as the object of interventions. This limits the role of contestation — the very quality Flanagan argues is core to the development of an ethics of civic participation - which can also be understood as the basis of a more radical conception of citizenship (for a more detailed discussion, see Marsh et al., 2007). 
Overall Flanagan makes a welcome and well-argued case for studies of political socialisation to focus on the process of political development in a way that accounts for young people's perspectives, and the roles of emotion, identity, and context. This is a call that must be made more loudly within the discipline of political science, where normative, institutional, and individualised approaches to political engagement, and quantitative methods for measurement, have dominated. Flanagan argues we should view young people as valued citizens who can improve democracy in the present through increased engagement with political controversies, political processes, and decision-making. However, the central concern of the book is: How can we cultivate active citizens for the future? This is ultimately because the focus is on how to effect change in young people, and not what is required of social and political institutions and adult actors.

In recent years many western governments have rolled back support for youth affairs and advocacy, adopting neoliberal policies that emphasise individual responsibility and local level participation by reducing social welfare, discontinuing mechanisms that connect young people directly to government debate and decision-making, and advocating initiatives to promote youth enterprise. In this context, we should take seriously Flanagan's final call, in the tradition of Peter Levine, "to have a public conversation about the normative reasons for the civic programs that we propose" (p. 237). This should entail serious examination of the degree to which the design and quality of civics education produces tangible and desirable effects (Manning \& Edwards, 2013). Moreover, policy implications should not only consider how to strengthen engagement with young people in general but also creatively address persistent inequalities and exclusion that many young people perceive in existing policies and programs (Vromen, 2012). Harris (2012) reminds us that even policy discourses that promote young people's participation can produce categories of exclusion and "failed citizenship" for those who don't meet normative expectations of the actualising, resourceful, entrepreneurial young citizen.

Nevertheless, in this highly accessible book, Flanagan demonstrates there are multiple ways young people develop political theories and that the relationships and activities that constitute this learning (in the family, in school, in communities) in fact shape the communities and society they live in. Political socialisation is therefore a fundamentally dynamic process, and requires more creative and engaged forms of policy-making and practice. The development of the political theories of the young is not straightforward, simple, or linear. Rather, the political theories of the young represent a process of life-work: of coming to know, to contest, to define, and to shape the political contours of society. 
International Journal of Child, Youth and Family Studies (2015) 6(4.1): 771-777

\section{References}

boyd, d. (2014). It's complicated: The social lives of networked teens. New Haven, CT: Yale University Press.

Chadwick, A. (2007). Digital network repertoires and organizational hybridity. Political Communication, 24, 283-301. http://dx.doi.org/10.1080/10584600701471666

Coleman, S., \& Rowe, C. (2005) Remixing citizenship: Democracy and young people's use of the internet. London, UK: Carnegie Young People Initiative.

Collin, P. (2008). Young people imagining a new democracy: A literature review. Sydney, Australia: The Whitlam Institute.

Collin, P. (2015). Young citizens and political participation: Addressing the democratic disconnect. Basingstoke, UK: Palgrave Macmillan. http://dx.doi.org/10.1057/9781137348838

Edwards, K. (2012). Political socialisation. In R. Smith, A. Vromen, \& I. Cook, (Eds.), Contemporary politics in Australia: Theories, practices and issues (pp. 83-93). Cambridge, UK: Cambridge University Press. http://dx.doi.org/10.1017/cbo9781139192552

Frazer, E. \& Emler, N. (1997). Participation and citizenship: A new agenda for youth politics research? In J. Bynner, L. Chisholm, \& A. Furlong (Eds.), Youth, citizenship and social change in a European context (pp. 171-195). Brookfield, VT: Ashgate Publishing.

Harris, A. (2012). Citizenship Stories. In N. Lesko \& S. Talburt, (Eds.), Keywords in youth studies: Tracing affects, movements, knowledges (pp. 143-152). New York, NY: Routledge. http://dx.doi.org/10.4324/9780203805909

Harris, A. (2013). Young people and everyday multiculturalism. New York, NY: Routledge. http://dx.doi.org/10.4324/9780203082980

Harris, A., Wyn, J., \& Younes, S. (2007). Young people and citizenship: An everyday perspective. Youth Studies Australia, 26(3), 19-27.

Henn, M., Weinstein, M., \& Wring, D. (2002). A generation apart? Youth and political participation in Britain. British Journal of Politics and International Relations, 4(2), 167-192. http://dx.doi.org/10.1111/1467-856x.t01-1-00001

Lister, R. (2008). Unpacking children's citizenship. In J. Williams \& A. Invernizzi, (Eds.), Children and citizenship (1st ed.) (pp. 9-19). London, UK: Sage. http://dx.doi.org/10.4135/9781446214756.n1

Loader, B. D., Vromen, A., \& Xenos, M. A. (2014). The networked young citizen: Social media, political participation and civic engagement. Information, Communication \& Society, 17, 143-150. http://dx.doi.org/10.1080/1369118x.2013.871571

Manning, N., \& Edwards, K. (2013). Does civic education for young people increase political participation? A systematic review. Educational Review, 66(1), 22-45. http://dx.doi.org/10.1080/00131911.2013.763767

Marsh, D., O’Toole, T., \& Jones, S. (2007). Young people and politics in the UK: Apathy or alienation? Basingstoke, UK: Palgrave Macmillan. http://dx.doi.org/10.1057/9780230625631 
International Journal of Child, Youth and Family Studies (2015) 6(4.1): 771-777

Norris, P. (2002). Democratic phoenix: Reinventing political activism, Cambridge, UK: Cambridge University Press. http://dx.doi.org/10.1017/cbo9780511610073

Norris, P. (2003). Young people and political activism: From the politics of loyalties to the politics of choice? Cambridge, MA: J.F Kennedy School of Government.

Putnam, R. (2000). Bowling alone. The collapse and revival of American community. New York, NY: Simon \& Schuster.

Stanyer, J. (2005). The British public and political attitude expression: The emergence of a self-expressive political culture? Contemporary Politics, 11(1), 19-32. http://dx.doi.org/10.1080/13569770500098623

Vromen, A. (2003). 'People try to put us down... ': Participatory citizenship of 'Generation X'. Australian Journal of Political Science, 38(1), 79-99. http://dx.doi.org/10.1080/1036114032000056260

Vromen, A. (2007). Australian young people's participatory practices and internet use. Information, Communication \& Society, 10(1), 48-68. http://dx.doi.org/10.1080/13691180701193044

Vromen, A. (2011). Constructing Australian youth online. Information, Communication and Society, 14, 959-980. http://dx.doi.org/10.1080/1369118x.2010.549236

Vromen, A. (2012). Youth participation from the top down: The perspectives of government and community sector decision makers in Australia. In J. Van Deth \& W. Maloney, (Eds.), New participatory dimensions in civil society: Professionalization and individualized collective action (pp. 212-230). Abingdon, UK: Routledge. http://dx.doi.org/10.4324/9780203142738

Vromen, A., \& Collin, P. (2010). Everyday youth participation? Contrasting views from Australian policymakers and young people. Young: Nordic Journal Of Youth Research, 18(1), 97-112. http://dx.doi.org/10.1177/110330880901800107

Xenos, M., Vromen, A., \& Loader, B. D. (2014). The great equalizer? Patterns of social media use and youth political engagement in three advanced democracies. Information, Communication \& Society, 17(2), 151-167. http://dx.doi.org/10.1080/1369118x.2013.871318 